\title{
Working with survivors
}

\author{
Stuart Turner, Consultant Psychiatrist, and Trustee, The Medical Foundation for \\ the Care of Victims of Torture, Insull Wing, National Temperance Hospital, \\ Hampstead Road, London NW1
}

As I walked into the waiting room, I remember being struck by his appearance. Although he was almost exactly my age, I saw an old, tired-looking, whitehaired man, his face deeply lined and drawn. I wondered what I had to offer this survivor of torture. Would I be able to help him recover from such a dreadful trauma? How could anyone come to terms with an experience which seemed to threaten some of the most basic human needs?

This was the first of many referrals from my colleagues in the Medical Foundation. I learned a great deal from him. For example, I got to know the real meaning of words which I had only ever come across in books and journal articles. I knew that falaka was a term applied to a form of torture in which the soles of the feet are beaten with a cane. I had to be told about the pain this causes, not just the first time as the soles of the feet are reduced to bleeding open wounds, but on each subsequent occasion as the scars (by now probably infected) are opened again and again. Even years later, it is often unbearably painful to walk more than a few hundred yards.

More than this, I learned that the worst aspect of his experience was not the personal suffering, but being forced to witness the torture and the deaths of others. Sham executions were often combined with genuine killings. After facing a firing squad, he would sometimes be the only one they did not kill. And the deaths were usually not accomplished so cleanly. In the dark crowded cells, people would be returned from torture only to die several hours later, without any possibility of relief in their final agonies.

In some ways this man is lucky. He is one of the survivors of torture. He had escaped from his own country and had been granted political asylum. He is relatively safe from further attack. Yet his life could never again be the same. He knew that he had been betrayed by a member of his family, someone to whom he had been particularly close. He would never again be able to trust or to live as freely as before. He would carry the chains of his torture to his death.

\section{Torture in the twentieth century}

Torture has been described as a "plague" which has now reached "epidemic proportions" (Pilisuk \& Ober, 1976). Although it is prohibited under the
Universal Declaration of Human Rights (United Nations, 1948), and the Convention against Torture (United Nations, 1984), it is widely used by state authorities throughout the world as an instrument of interrogation and systematic repression. Amnesty International (1987) reports that brutal torture and ill-treatment have been practised in the 1980 s by one out of every three governments.

Under the recent UN convention, torture is defined as an activity carried out by, or with the consent of, a person acting in an official capacity. In its nature, therefore, it is an action of a state against an individual. But not just an individual. For every person tortured, there are many friends and relatives who wait in uncertainty and in fear.

Represssion of political and religious opposition is often a primary objective together with the extraction of forced confessions and names of accomplices. In Argentina, a book of testimonies which records many examples of torture has been published. A doctor who had chosen to work with the poor reports, for example, that the torturers told him they "knew I was not involved with terrorism or the guerrillas, but that they were going to torture me because I opposed the regime". They also said "You're going to pay dearly for it... the poor won't have any goodygoodies to look after them any more!" (Argentina's National Commission on Disappeared People, 1986).

\section{Psychological reactions to torture.}

The individual surviving such a concentrated attack is inevitably changed. The post traumatic sequelae have been described "as a form of bondage through which the torturer ensures that his interventions will last over time". Seen in this way, the "rehabilitative aim is centred on the purpose of freeing victims" from these shackles (Schlapobersky \& Bamber, 1988).

Specific patterns of response have been described. Probably the best known of these is Post Traumatic Stress Disorder (PTSD) (DSM-IIIR; American Psychiatric Association, 1987). This state is characterised by exposure to an event outside the range of usual human experience (e.g. torture); persistent 
re-experiencing of the event in thought, dreams or flashbacks; persistent avoidance of stimuli associated with the trauma or a more general emotional numbing; persistent symptoms of increased arousal; duration of at least one month.

My patient told me about intrusive thoughts in which he recalled his own experiences under torture and the sight and sounds of others being tortured or killed. He tried to avoid thinking about the torture (and often succeeded) but became very upset and tearful when these memories broke through into consciousness. His sleep was disturbed by nightmares and he would often wake up with his fists clenched and feeling very frightened. He described a marked loss of interest, a sense of hopelessness and an impaired ability to enjoy the normal things in life. He was able to acknowledge that he had had thoughts of suicide.

Others have talked more about the way this experience has affected so profoundly their view of themselves and of humanity. The horror that they have endured may be irreconcilable with their previous religious, political or social assumptions. Their world often seems empty, their life without meaning. Sometimes the only purpose they can see for living comes from the knowledge that by their death, the torturer would finally have defeated them.

\section{Seeking asylum}

Having suffered experiences such as these, it is hardly surprising that many attempt to escape from the country where the torture took place. This may place them at increased risk for a while, as they try to obtain documents (often false) or to bribe their way out. Arriving in a new country, they need to make an application for refugee status.

A refugee has been defined in another UN convention (United Nations, 1951) as a person who owing to a "well founded fear of being persecuted for reasons of race, religion, nationality, membership of a particular social group or political opinion" has left his own country and is unable to return. Refugee status carries important rights for the protection and the well-being of the individual.

The United Nations High Commission for Refugees estimate that there are about 140,000 refugees in the United Kingdom (Nettleton \& Simcock, 1987). Many of these are long-term residents. Almost half a million people from Europe sought refuge in Britain prior to, during and immediately after World War II. Between 1980 and 1986 there were 26,491 applications for asylum from which 14,504 people were granted refugee status (or "exceptional leave" to remain in the UK) and 4,764 were refused. A small number withdrew their applications and the rest were awaiting decisions (Nettleton \& Simcock, 1987). Many of these asylum seekers have suffered torture or other forms of organised state violence.

\section{The Medical Foundation}

Of the survivors who enter the UK to seek asylum, many now come to the attention of the Medical Foundation. This is a London based independent charity formed in December 1985 to continue the work carried out for more than a decade by volunteer practitioners under the auspices of the British Section of Amnesty International. In its first full operational year (1986), seventy five new patients were seen. It is estimated that over five hundred new patients will present this year (1988).

The work of the Medical Foundation is carried out by a group of volunteer professionals, supported by a small core team of paid staff. At the moment, the volunteers providing regular assistance to survivors of torture include 13 examining doctors, 6 psychiatrists, 6 psychotherapists, 3 physiotherapists, 3 social workers, 2 nurses, 1 psychologist, 1 occupational therapist, 1 art therapist and 1 careers counsellor. Many patients are seen in evening clinics after the normal day's work has finished.

A sense of continuity of place appears to be important; for people who have an almost overwhelming barrier to the formation of trusting relationships, it helps if the environment in which they are seen is familiar to them and has positive associations. All volunteers are therefore encouraged to use the offices at the Foundation for their work. Although the accommodation which the Foundation now occupies will only be available for a limited period and thought is already being given to the daunting task of acquiring a permanent home, the present offices have a special importance to many of our patients.

In the same way, a fairly relaxed approach to timekeeping seems necessary with patients not infrequently missing appointments or turning up late. Perhaps this has something to do with a need to regain control over their own lives. Patients often drop into the Foundation at odd times, only gradually learning to trust.

\section{The clinical work of the Medical Foundation}

\section{Medico-legal assessments}

One of the first tasks undertaken by the Medical Group of Amnesty International's British Section was the examination of people who alleged that they had been tortured to see if their claims could be verified. These case descriptions, with their objective medical examinations, were important elements in Amnesty's campaigning work against the use of torture.

The preparation of independent social, medical and psychiatric reports is now an important aspect of 
the Medical Foundation's clinical work with individual survivors. For those who have just entered the UK and who have made an application for asylum, the first priority is to document the history of torture and to describe in detail any abnormalities on physical or psychiatric examination. These reports are made available to the patient's legal advisers and are used in connection with the formal application for asylum.

Frequently, there is very little time in which to prepare these detailed reports. This means that the pace of history-taking is sometimes faster than might otherwise appear desirable. It is inevitably the case that the most distressing aspects of the torture experience are the most important in a report dealing with the evidence of torture. As it is essential that anything remotely resembling interrogation is avoided, this means that time and patience must be afforded.

A method of practice has developed therefore in which the initial interview(s) are often lengthy and aim to cover the person's experiences in minute detail. Careful attention is given to details such as size of cell, number of occupants, provision of food and water, sanitation, behaviour of guards, sensory deprivation, dates of each event (when these can be remembered) and description of the forms and frequency of torture. The range and severity of present symptoms are also described, together with evidence of abnormalities on physical or mental state examination.

The preparation of this asylum report is often an important first step in the process of recovery. It shares some of the attributes of the testimony statement used in therapy by a Chilean group (Cienfuegos \& Monelli, 1983). It may also provide additional medical evidence of torture in support of the asylum application. It is our experience that people seeking asylum, who have been treated harshly by the authorities in their country of origin, are often uncertain how much to reveal to the British authorities when they arrive in the UK. They may choose to conceal important events which would have strengthened their case. Sometimes in an unhurried, independent professional assessment it is easier for people to mention these experiences.

The psychiatric assessment is often crucial in cases where people describe having been tortured, but where they no longer bear any physical evidence. It is important for the doctor to be familiar with the full range of typical reactions to torture. Sometimes a formal psychological assessment is also helpful in individuals who describe cognitive impairment following torture.

\section{Medical and psychosocial crises}

There may be urgent social, medical, legal or financial needs. In cooperation with other agencies, one of the Medical Foundation's case-workers or examining doctors may be required to make an urgent assessment. This aspect of the work is currently limited by lack of resources but help is offered whenever possible. The Medical Foundation is fortunate in having established a network of sympathetic professionals willing to see patients quickly. Although anyone who has applied for asylum in the UK is eligible for NHS treatment, particular care has to be taken in the treatment of torture survivors. Somatisation is a common problem and requires expert assessment. In addition, there is sometimes a fear of certain physical investigations (for example the application of electrical contacts in the ECG) which resemble aspects of the torture experience.

\section{Rehabilitation and recovery}

Increasingly, physical and psycho-social rehabilitation work is the major focus of work in the Medical Foundation. Physical disorders are treated where possible by one of the examining doctors, nurses or physiotherapists. The damage to the feet following falaka, for example, requires a multiprofessional approach in which physiotherapy has an important role.

A psychiatric assessment at this point is usually problem orientated. Particular attention is paid to physical symptoms which may have a psychological basis. Schlapobersky \& Bamber (1988) have written that the "separation of body from mind (psyche from soma) is nowhere less appropriate than in the treatment of survivors of torture where the body has been abused to gain access to the mind".

One common reaction to torture appears to be the development of a hyperventilation syndrome. During torture, some people adopt behaviours which reduce the impact of the experience. Voluntary headbanging to induce unconsciousness or hyperventilation to induce an abnormal mental state are two examples. Chronic hyperventilation disorder, which may develop as a late complication, usually presents with a wide range of physical symptoms. Explanation and demonstration are often useful in altering the patient's attribution. Breathing retraining by a physiotherapist coupled with psychotherapy are often effective in relieving this symptom.

One of the more sedating of the tricyclic antidepressants often appears to produce relief in people with evidence of a depressive disorder and may also reduce some of the intrusive phenomena seen in PTSD (also reported by Boehnlein et al, 1985).

In addition to the beneficial effects of testimony as described above, the longer term psychotherapeutic work is usually based on a psychodynamic approach. Volunteer therapists offer individual, marital, family and group psychotherapy. Important themes in the psychotherapeutic work include the restoration of 
personal dignity and hope, the opening up of new areas of interest independent of the torture memories and the reclaiming of personal space and value.

Group work is often particularly valuable but is not without its complications. The political dimension imposes the restriction that (generally) no two people from the same country can be in the same group. People entering the group have to be confident that their condition and their confidences will not be betrayed by someone else with different political opinions from the same country.

Paradoxically, this meeting of people from different cultures can often be very powerful; the ability to recognise problems and distress in others and to reach out to try and help may be one of the first stages in achieving a personal resolution of past traumas and a new hope for the future.

\section{Conclusion}

Torture is a hideous infringement of basic human rights. It drives people to despair and sometimes into flight. Those who seek asylum in the UK are increasingly presenting for help at the Medical Foundation for the Care of Victims of Torture. In 1988, over five hundred new casses will have been seen. In this paper, an overview of the work of the Medical Foundation has been presented.

As the demands on the service increase, it becomes more important to evaluate each different element. This will be an increasing priority and will form part of a programme of research. In parallel with this development is the need to share the skills which we have developed in this work with others in this country and abroad.

For the future, we hope to be able to continue and to develop this service to the survivors of torture. We have to face the demand for a permanent base for the Medical Foundation. There will inevitably be financial worries as we seek to retain our independence and there is always a need to make contact with practitioners willing to offer some of their time and energy to this difficult work.
Finally, to return to my first patient, he is still attending the Medical Foundation, although less frequently. He has made a good personal recovery and is now in employment although he has not been able to return to his previous occupational status. $\mathrm{He}$ is much more optimistic for the future, but knows that he will never forget his pain or the tragic scenes which he was forced to witness.

\section{References}

American Psychiatric Association (1987) Diagnostic and Statistical Manual of Mental Disorders, Third Edition, Revised. Washington DC: American Psychiatric Association.

AMNESTY INTERNATIONAL (1987) Amnesty International Report 1987. London: Amnesty International Publications.

Argentina's National Commission on Disappeared People (1986) Nunca Mas (Never Again). London: Faber \& Faber.

Boehnlein, J. K., KinzIE, J. D., BEN, R. \& FleCK, J. (1985) One-year follow-up study of posttraumatic stress disorder among survivors of Cambodian concentration camps. American Journal of Psychiatry, 142, 956-959.

Cienfuegos, A. J. \& Monelli, C. (1983) The testimony of political repression as a therapeutic instrument. American Journal of Orthopsychiatry, 53, 43-51.

Nettleton, C. \& Simcock, A. (1987) Asylum-seekers in the United Kingdom: Essential Statistics. London: British Refugee Council Research and Development Unit.

PILISUK, M. \& OBER, L. (1976) Torture and genocide as public health problems. American Journal of Orthopsychiatry, 46, 388-392.

SCHLAPOBERSKY, J. \& BAMBER, H. (1988) Rehabilitation and therapy with the victims of torture amd organised violence. Paper presented to the American Association for the Advancement of Science (Annual meeting).

UNITED NATIONS (1948) Universal Declaration of Human Rights. Office of Public Information. New York: United Nations.

(1951) Convention relating to the Status of Refugees. Office of Public Information. New York: United Nations.

(1984) Convention against torture and other cruel, inhuman or degrading treatment or punishment. Office of Public Information. New York: United Nations. 